\title{
Kinetics of the Leaching Process of an Australian Gibbsitic Bauxite by Hydrochloric Acid
}

\author{
Aichun Zhao, ${ }^{1,2}$ Ting-an Zhang, ${ }^{3}$ Guozhi Lv, ${ }^{3}$ and Wenyan Tian ${ }^{4}$ \\ ${ }^{1}$ School of Material Science and Engineering, Taiyuan University of Science and Technology, Taiyuan 030024, China \\ ${ }^{2}$ Collaborative Innovation Center of Taiyuan Heavy Machinery Equipment, Taiyuan University of Science and Technology, \\ Taiyuan 030024, China \\ ${ }^{3}$ Key Laboratory of Ecological Utilization of Multi-Metal Intergrown Ores of Ministry of Education, Northeastern University, \\ Shenyang 110819, China \\ ${ }^{4}$ School of Electronic Information Engineering, Taiyuan University of Science and Technology, Taiyuan 030024, China
}

Correspondence should be addressed to Aichun Zhao; zhaoaichun1985@126.com and Ting-an Zhang; zta2000@163.net

Received 23 February 2016; Revised 5 June 2016; Accepted 6 June 2016

Academic Editor: Luigi Nicolais

Copyright @ 2016 Aichun Zhao et al. This is an open access article distributed under the Creative Commons Attribution License, which permits unrestricted use, distribution, and reproduction in any medium, provided the original work is properly cited.

\begin{abstract}
Gibbsitic bauxite from Australia was leached by hydrochloric acid in this work. Analysis on kinetics for the extraction of $\mathrm{Al}_{2} \mathrm{O}_{3}$ was quantitatively studied. It was concluded that the hydrochloric acid leaching process of gibbsitic bauxite was controlled by chemical reaction. Moreover, the mechanism for the dissolution followed the equation, $\ln k=39.44-1.66 \times 10^{4}(1 / T)$, with an apparent activation energy of $137.90 \mathrm{~kJ} / \mathrm{mol}$, according to the equation of $k=A e^{-E_{a} / R T}$. This work aims to provide a good theory support for the process control by using a new method of alumina production from the low grade bauxite.
\end{abstract}

\section{Introduction}

It is well known that the Bayer process is the main method to extract alumina from the bauxite in the world [1-9]. However, Bayer process is only suitable for the treatment of high grade bauxite ore. With the development of alumina production capacity, the resources of high quality bauxite are decreasing year by year $[10,11]$. If alumina is produced from the mineral which has a ratio of $\mathrm{Al}_{2} \mathrm{O}_{3} / \mathrm{SiO}_{2}$ in the range of 2 by Bayer process, the dissolution rate of alumina is only $50 \%$.

Alumina is produced using the low grade bauxite and nontraditional bauxite resources, which has attracted wide attention from industry and academic fields. Based on the previous results reported by the authors, the double cycling method has been successfully applied to produce alumina from the low grade bauxite $[12,13]$. Firstly, the bauxite is extracted by hydrochloric acid solution. Thereafter, the iron ion and aluminum ion in the leached solution are separated by the liquid-liquid extraction route. Finally, the aluminum chloride solution is directly pyrolysised to prepare alumina product. Hydrogen chloride gas which is vapored in the pyrolysis process is achieved to cycle.

In previous studies $[12,13]$, the thermodynamic analysis and the effects of several parameters, such as temperature, leaching time, stirring speed of the impeller, and concentration of acidic solution, have been studied. However, the kinetic mechanism of the bauxite dissolution in the acidic solution has not been found in the previous reports. In this case, the present work quantitatively investigates the kinetic mechanism of the leaching process of bauxite in the hydrochloric acid solution. This work aims to give a good theory support for the process control of a new method of alumina production from the low grade bauxite.

\section{Experiment}

The raw material of bauxite was from Alcoa Australia Co. $\mathrm{X}$-ray fluorescence analyzer (XRF) combined with chemical analysis was used for the qualitative analysis of the sample composition. The results are shown in Table 1. Moreover, the 
TABLE 1: Chemical compositions of raw bauxite mineral.

\begin{tabular}{lccccccc}
\hline $\begin{array}{l}\text { Chemical } \\
\text { compositions }\end{array}$ & $\mathrm{Al}_{2} \mathrm{O}_{3}$ & $\mathrm{SiO}_{2}$ & $\mathrm{Fe}_{2} \mathrm{O}_{3}$ & $\mathrm{TiO}_{2}$ & $\mathrm{CaO}$ & $\mathrm{MgO}$ & LOI \\
\hline $\begin{array}{l}\text { Content (wt } \\
\text { pct) }\end{array}$ & 38.51 & 18.58 & 19.26 & 1.09 & 0.05 & 0.08 & 22.20 \\
\hline
\end{tabular}

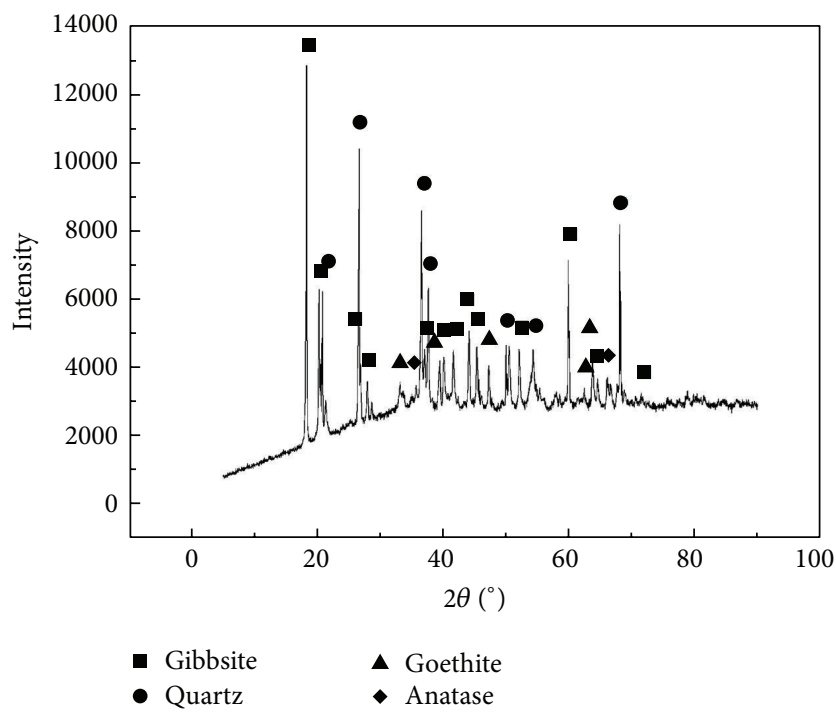

FIGURE 1: XRD patterns of raw ore.

$\mathrm{X}$-ray diffraction (XRD) technique was used to identify the phases in the raw bauxite and the slag after leaching. The results are shown in Figure 1.

According to the analysis results as shown in Table 1 and Figure 1, it can be seen that the main phase of bauxite is gibbsite. Besides, the goethite, quartz, and anatase phases are also included in the raw bauxite. This raw material is considered to be with a low aluminum content of $38.51 \%$ and with a low ratio of aluminum to silicon and a high iron content. And LOI does not contain materials which are easy to react with acid. Finally it is recognized that this raw material is a typical low grade gibbsite which is difficult to deal with the normal methods. If alumina is dissoluted using Bayer process, iron minerals will enter the residue of the red mud which can not be directly effectively used [8]. However, the present double cycle method can achieve the recycling of iron and aluminum at the same time. In addition, this raw bauxite is a kind of material which is suitable for investigating the kinetics of the acid leaching of bauxite. And major chemical reactions that can occur during production of alumina are shown as follows:

$$
\begin{aligned}
& \mathrm{Al}(\mathrm{OH})_{3}(\mathrm{~s})+3 \mathrm{H}^{+}=\mathrm{Al}^{3+}(\mathrm{aq})+3 \mathrm{H}_{2} \mathrm{O} \\
& \mathrm{FeO}(\mathrm{OH})(\mathrm{s})+3 \mathrm{H}^{+}=\mathrm{Fe}^{3+}(\mathrm{aq})+2 \mathrm{H}_{2} \mathrm{O}
\end{aligned}
$$

The high pressure vessel with the inner lining material of zirconium which is called KCFD2-10 type was used to study the leaching process of bauxite in hydrochloric acid solution with adding volume of $150 \mathrm{~mL}$ each time. The inductively coupled plasma optical emission spectrometry (ICP-OES)
TABLE 2: Effect of leaching time and leaching temperature on extraction of $\mathrm{Al}_{2} \mathrm{O}_{3}$ and $\mathrm{Fe}_{2} \mathrm{O}_{3}$.

\begin{tabular}{lccc}
\hline $\begin{array}{l}\text { Leaching } \\
\text { temperature } /{ }^{\circ} \mathrm{C}\end{array}$ & $\begin{array}{c}\text { Leaching } \\
\text { time/min }\end{array}$ & $\begin{array}{c}\text { Fraction of } \\
\mathrm{Al}_{2} \mathrm{O}_{3} \\
\text { extracted/\% }\end{array}$ & $\begin{array}{c}\text { Fraction of } \\
\mathrm{Fe}_{2} \mathrm{O}_{3} \\
\text { extracted/\% }\end{array}$ \\
\hline 80 & 30 & 34.55 & 78.87 \\
80 & 60 & 43.88 & 79.92 \\
80 & 90 & 47.34 & 90.34 \\
80 & 120 & 54.43 & 93.93 \\
90 & 30 & 49.73 & 75.43 \\
90 & 90 & 52.79 & 94.42 \\
90 & 120 & 75.26 & 92.23 \\
\hline
\end{tabular}

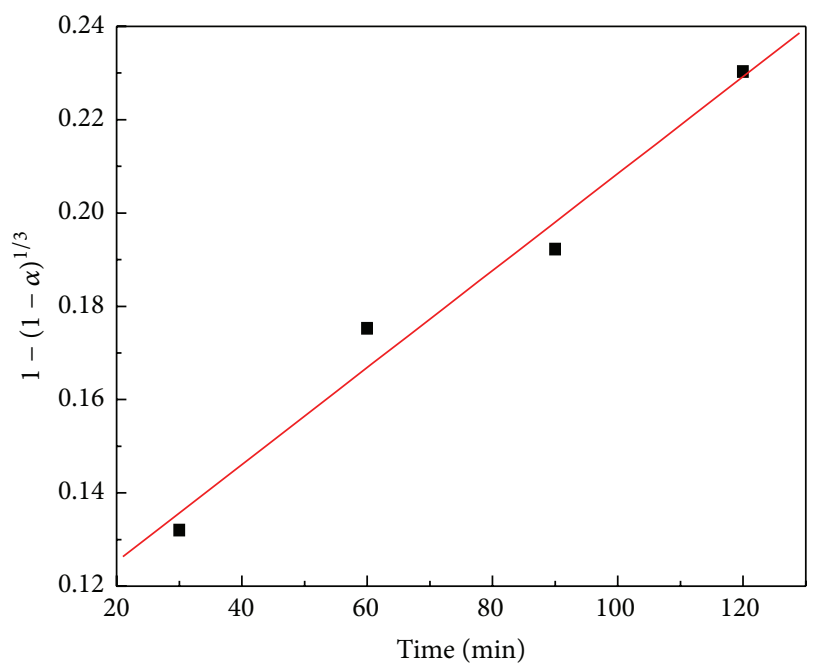

FIgURE 2: Leaching kinetics fitting curve of aluminum ion.

instrument with a Prodigy XP type (Le Mans, USA) was used to detect the concentrations of aluminum ion and threevalent iron ion in the leaching solution after acid leaching process. The detailed information of the experiments could be found in previous studies $[12,13]$.

\section{Results and Discussions}

The effect of leaching time on the kinetic study of the extraction of $\mathrm{Al}_{2} \mathrm{O}_{3}$ and $\mathrm{Fe}_{2} \mathrm{O}_{3}$ using the hydrochloric acid solution is shown in Table 2 . The relationship curve between the function of $y=1-(1-\alpha)^{1 / 3}$ and the time is plotted in Figure 2.

Moreover, the linear fitted results according to the experimental data are also shown in Figure 2. Here, the leaching temperature is fixed to be $80^{\circ} \mathrm{C}$.

Based on the results in Figure 2, it is found that that the linear correlation coefficient of $R$ equals a value of 0.98803 , which shows a better fitting with the chemical reaction kinetics equation.

According to the Vantv differential method [14], the relationship between the isothermal reaction rate and the 
concentration of hydrogen ion is represented as the following equation:

$$
v=k C^{n}
$$

whereas $n$ is type of response, $v$ is reaction rate of hydrogen ion, and $C$ is hydrogen ion concentration. Thereafter, (3) is calculated on both sides of the logarithm, as shown in

$$
\begin{gathered}
\lg v=\lg k+n \lg C . \\
C=\frac{(40.5 \times 1.1837 \times 37 \%) / 36.5-3 \times((10.5 \times 58.59 \%) / 78) \alpha-6 \times((10.5 \times 19.26 \%) / 160) \beta}{0.15},
\end{gathered}
$$

According to the above equations, the effect of leaching time on the kinetics of the gibbsite dissolution in the acidic solution could be obtained by the experiment data. Thereafter, the related kinetic parameters can be obtained.

Firstly, the concentration of hydrogen ion at a certain time is determined, as shown in the following equation: whereas the volume of the concentrated hydrochloric acid used in the experiment is $40.5 \mathrm{~mL}$ and the density of concentrated hydrochloric acid is $1.1837 \mathrm{~g} / \mathrm{mL}$. The molar mass of concentrated hydrochloric acid is $36.5 \mathrm{~g} / \mathrm{mol}$. And the mass fraction of concentrated hydrochloric acid is $37 \%$. The adding amount of raw bauxite mineral is $10.5 \mathrm{gw}$. The content of aluminum hydroxide in the bauxite mineral is $58.59 \%$. The molar mass of aluminum hydroxide is $78 \mathrm{~g} / \mathrm{mol}$. The fraction of alumina extracted at a moment is marked as $\alpha$. The content of iron oxide in the ore is $19.26 \%$. The molar mass of iron oxide is $160 \mathrm{~g} / \mathrm{mol}$. The fraction of $\mathrm{Fe}_{2} \mathrm{O}_{3}$ extracted at a moment is marked as $\beta$. Finally, the approximate volume of the solution is $0.15 \mathrm{~L}$.

Based on the above data, the concentration of hydrogen ion in the solution at a certain time is shown in Table 3. Moreover, the relationship between the concentration of hydrogen ion at $80^{\circ} \mathrm{C}$ and the time is shown in Figure 3.

At the point where the hydrogen ion concentration is corresponding to $3.04,2.80,2.62$, and $2.36 \mathrm{~mol} / \mathrm{L}$, four oblique lines are drawn according to these data. The slopes of the four tangent lines are determined, and the reaction rates of the hydrogen ion concentration with four concentration values are summarized in Table 4.

Thereafter, the fitted curve based on relationship between $\lg v$ and $\lg C$ is shown in Figure 4. According to the experimental data, the linear correlation coefficient of $R$ is calculated with the value of 0.99362 .

From Figure 4, the slope of the line is calculated with a value of 3.97 , and the reaction order is 3.97 under this condition. In addition, the vertical coordinate value of the intersection between the line and $\lg C=0$ is calculated with the value of -3.28 . Therefore, according to (6), the reaction rate of $k$ is calculated with the value of $0.00053 \mathrm{~min}^{-1}$ :

$$
\lg k=-3.28
$$

Based on the relationship between the concentration of hydrogen ion and the time at $90^{\circ} \mathrm{C}$, the fitted curve is shown in Figure 5.

At the point where the hydrogen ion concentration is corresponding to $3.10,2.66,2.43$, and $2.21 \mathrm{~mol} / \mathrm{L}$, four oblique lines are drawn. The slopes of the four tangent lines are determined. By using these data, the reaction rates of the hydrogen ion concentration with four concentration values are shown in Table 5.

The relationship line between $\lg v$ and $\lg C$ is shown in Figure 6, and the linear correlation coefficient of $R$ is calculated with the value of 0.99368 .

The slope of the line is 3.10 ; hence the reaction order is 3.10. In addition the vertical coordinate value of the intersection between the line and $\lg C=0$ is calculated with the value of -2.71 . Thereafter, the reaction rate $k$ is calculated with the value of $0.0019 \mathrm{~min}^{-1}$, according to the following:

$$
\lg k=-2.71
$$

Moreover, (8) has been applied for the calculation:

$$
\ln \frac{k_{2}}{k_{1}}=-\frac{E_{a}}{R}\left(\frac{1}{T_{2}}-\frac{1}{T_{1}}\right) .
$$

The apparent activation energy of $E_{a}$ is calculated with the value of $137.90 \mathrm{~kJ} / \mathrm{mol}$, according to the following equation:

$$
\ln k=-\frac{E_{a}}{R T}+\ln A .
$$

Thereafter, the former factor $A$ could be calculated with the value of $1.35 \times 10^{17}$.

Finally, the apparent activation energy of the dissolution process of gibbsite in hydrochloric acid solution is calculated to be $137.90 \mathrm{~kJ} / \mathrm{mol}$. This result is under the condition of the closed system with its former factor $1.35 \times 10^{17}$. The kinetic equation of the gibbsite dissolution is shown in the following:

$$
\ln k=39.44-1.66 \times 10^{4} \frac{1}{T}
$$

Reddy et al. also studied kinetics of leaching of a gibbsitic bauxite with hydrochloric acid. But analyses on the leaching of iron oxide from bauxite by hydrochloric acid were mainly investigated. The activation energy was with average value of about $81.0 \mathrm{~kJ} / \mathrm{mol}[15]$.

\section{Conclusions}

This work presents a double cycling method, which is a new route to better control the extraction alumina in the 


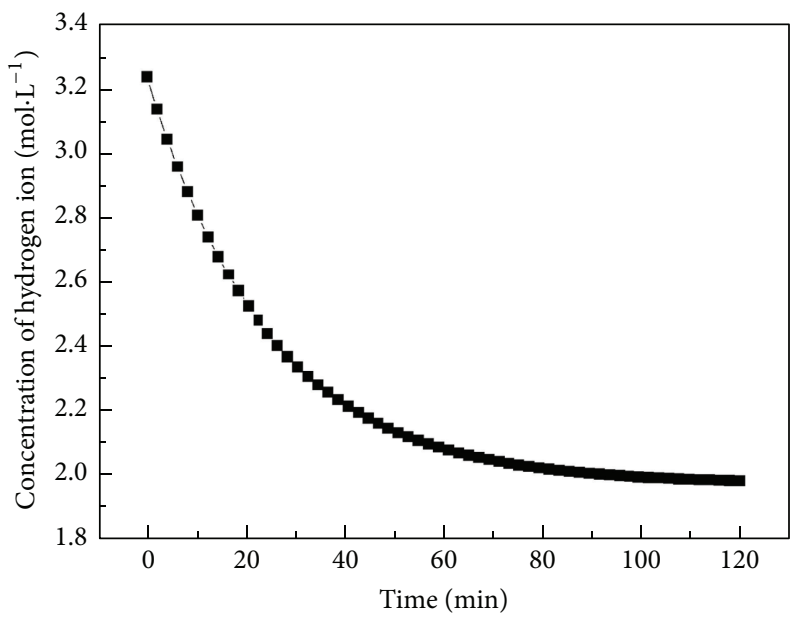

FIgURE 3: Hydrogen ion concentration at a given time (at $80^{\circ} \mathrm{C}$ ).

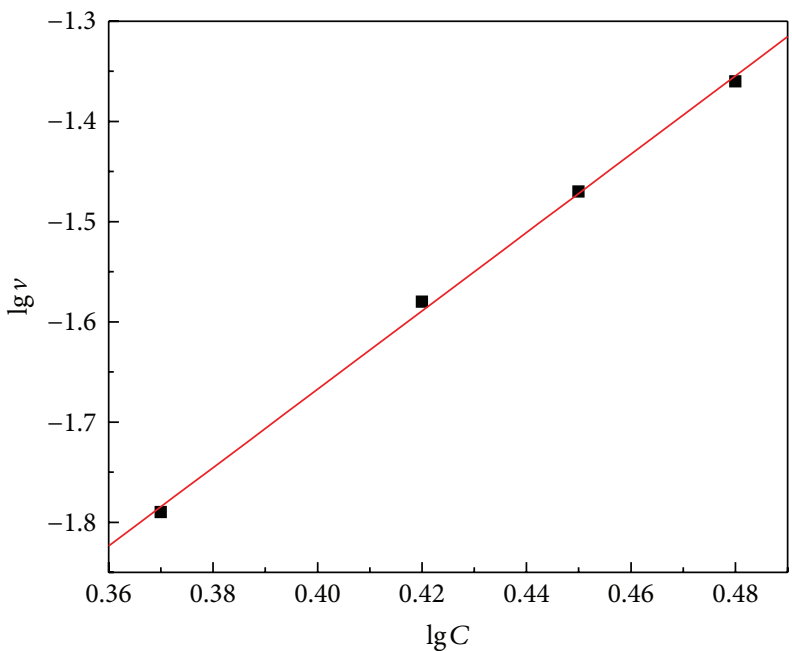

FIgURE 4: Relationship between $\lg v$ and $\lg C$ (at $80^{\circ} \mathrm{C}$ ).

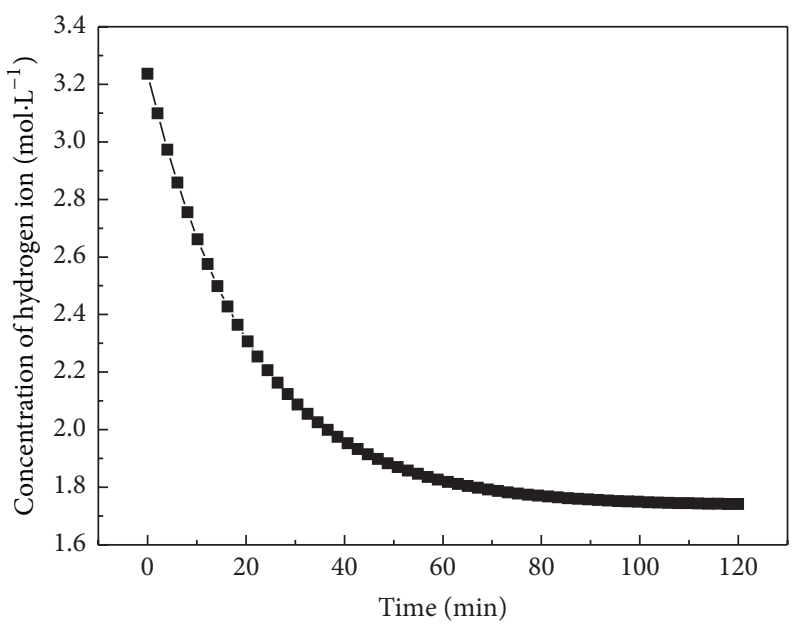

Figure 5: Hydrogen ion concentration at a given time (at $90^{\circ} \mathrm{C}$ ). 
TABLE 3: Hydrogen ion concentration at a given time.

\begin{tabular}{lcc}
\hline Leaching temperature $/{ }^{\circ} \mathrm{C}$ & Leaching time/min & Hydrogen ion concentration/(mol/L) \\
\hline 80 & 0 & 3.24 \\
80 & 30 & 2.30 \\
80 & 60 & 2.14 \\
80 & 90 & 2.04 \\
80 & 120 & 1.91 \\
90 & 0 & 3.24 \\
90 & 30 & 2.07 \\
90 & 90 & 1.93 \\
90 & 120 & 1.59 \\
\hline
\end{tabular}

TABLE 4: Reaction rates at the different concentrations (at $80^{\circ} \mathrm{C}$ ).

\begin{tabular}{|c|c|c|c|c|c|}
\hline Number & $\begin{array}{c}\text { Hydrogen ion } \\
\text { concentration/mol/L }(C) \\
\end{array}$ & $\lg C$ & Slope of the line & $\begin{array}{l}\text { Reaction rate of hydrogen } \\
\text { ion } / \mathrm{mol} \cdot \mathrm{L}^{-1} \cdot \mathrm{min}^{-1}(v)\end{array}$ & $\lg v$ \\
\hline 1 & 3.04 & 0.48 & -0.044 & 0.044 & -1.36 \\
\hline 2 & 2.80 & 0.45 & -0.034 & 0.034 & -1.47 \\
\hline 3 & 2.62 & 0.42 & -0.027 & 0.027 & -1.58 \\
\hline 4 & 2.36 & 0.37 & -0.016 & 0.016 & -1.79 \\
\hline
\end{tabular}

TABLE 5: Reaction rates at the different concentrations (at $90^{\circ} \mathrm{C}$ ).

\begin{tabular}{|c|c|c|c|c|c|}
\hline Number & $\begin{array}{c}\text { Hydrogen ion } \\
\text { concentration/mol/L }(C)\end{array}$ & $\lg C$ & Slope of the line & $\begin{array}{l}\text { Reaction rate of hydrogen } \\
\text { ion } / \mathrm{mol} \cdot \mathrm{L}^{-1} \cdot \mathrm{min}^{-1}(v)\end{array}$ & $\lg v$ \\
\hline 1 & 3.10 & 0.49 & -0.065 & 0.065 & -1.19 \\
\hline 2 & 2.66 & 0.43 & -0.044 & 0.044 & -1.36 \\
\hline 3 & 2.43 & 0.39 & -0.033 & 0.033 & -1.48 \\
\hline 4 & 2.21 & 0.34 & -0.022 & 0.022 & -1.65 \\
\hline
\end{tabular}

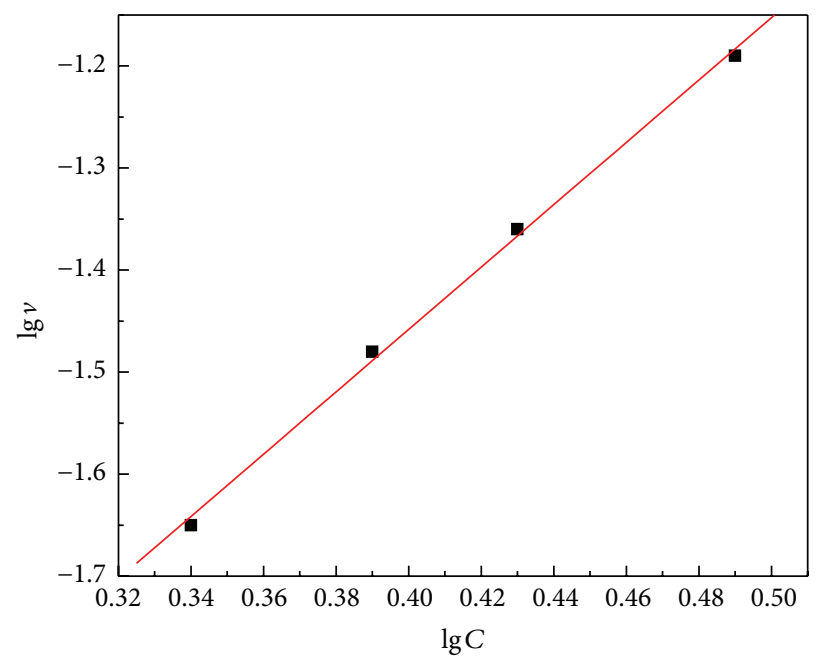

FIgURE 6: Relationship between $\lg v$ and $\lg C\left(\right.$ at $\left.90^{\circ} \mathrm{C}\right)$. 
hydrochloric acid solution. The kinetic study showed that the hydrochloric acid leaching process of gibbsitic bauxite was controlled by chemical reaction. The final kinetic equation is $\ln k=39.44-1.66 \times 10^{4}(1 / T)$.

\section{Competing Interests}

The authors declare that they have no competing interests.

\section{Acknowledgments}

The authors would like to thank the financial support of the Doctor Start Up Foundation in Taiyuan University of Science and Technology (no. 20142001). The National Natural Science Foundation of China (no. 51004033 and no. 61401298) and Natural Science Foundation of Shanxi Province (no. 2015021094) are also acknowledged.

\section{References}

[1] G. Z. Lü, T. A. Zhang, X. F. Zhu et al., "Calcification-carbonation method for cleaner alumina production and $\mathrm{CO}_{2}$ utilization," JOM, vol. 66, no. 9, pp. 1616-1621, 2014.

[2] H. Li, Research on sustainable development of bauxite resources industry in China [Ph.D. dissertation], China University of Geosciences, Beijing, China, 2010.

[3] X. L. Pan, H. Y. Yu, K. W. Dong, G. F. Tu, and S. W. Bi, "Predesilication and digestion of gibbsitic bauxite with lime in sodium aluminate liquor," International Journal of Minerals, Metallurgy, and Materials, vol. 19, no. 11, pp. 973-977, 2012.

[4] G. Power and J. Loh, "Organic compounds in the processing of lateritic bauxites to alumina-Part 1: origins and chemistry of organics in the Bayer process," Hydrometallurgy, vol. 105, no. 12, pp. 1-29, 2010.

[5] H. X. Li, J. Addai-Mensah, J. C. Thomas, and A. R. Gerson, “The crystallization mechanism of $\mathrm{Al}(\mathrm{OH})_{3}$ from sodium aluminate solutions," Journal of Crystal Growth, vol. 279, no. 3-4, pp. 508520, 2005.

[6] A. R. Hind, S. K. Bhargava, and S. C. Grocott, "The surface chemistry of Bayer process solids: a review," Colloids and Surfaces A: Physicochemical and Engineering Aspects, vol. 146, no. 1-3, pp. 359-374, 1999.

[7] S. N. M. Hairi, G. N. L. Jameson, J. J. Rogers, and K. J. D. MacKenzie, "Synthesis and properties of inorganic polymers (geopolymers) derived from Bayer process residue (red mud) and bauxite," Journal of Materials Science, vol. 50, no. 23, pp. 7713-7724, 2015.

[8] M. S. R. Sarker, M. Z. Alam, M. R. Qadir, M. A. Gafur, and M. Moniruzzaman, "Extraction and characterization of alumina nanopowders from aluminum dross by acid dissolution process," International Journal of Minerals, Metallurgy and Materials, vol. 22, no. 4, pp. 429-436, 2015.

[9] A. Adamson, E. Bloore, and A. Carr, Essential Readings in Light Metals, Alumina and Bauxite, John Wiley \& Sons, Hoboken, NJ, USA, 2013.

[10] G. Power, M. Gräfe, and C. Klauber, "Bauxite residue issues: I. Current management, disposal and storage practices," Hydrometallurgy, vol. 108, no. 1-2, pp. 33-45, 2011.

[11] M. Authier-Martin, G. Forté, S. Ostap, and J. See, “The mineralogy of bauxite for producing smelter-grade alumina," Journal of the Minerals, Metals \& Materials Society, vol. 53, no. 12, pp. 36-40, 2001.

[12] A. C. Zhao, Basic study on bauxite with high iron content by acid process [Ph.D. thesis], Northeastern University, Shenyang, China, 2013.

[13] A.-C. Zhao, Y. Liu, T.-A. Zhang, G.-Z. Lü, and Z.-H. Dou, “Thermodynamics study on leaching process of gibbsitic bauxite by hydrochloric acid," Transactions of Nonferrous Metals Society of China, vol. 23, no. 1, pp. 266-270, 2013.

[14] G. S. Wupadaye and R. K. Dube, Application Calculation of Thermodynamics and Kinetics of Metallurgy, Metallurgical Industry Press, Beijing, China, 1981.

[15] B. R. Reddy, S. K. Mishra, and G. N. Banerjee, "Kinetics of leaching of a gibbsitic bauxite with hydrochloric acid," Hydrometallurgy, vol. 51, no. 1, pp. 131-138, 1999. 

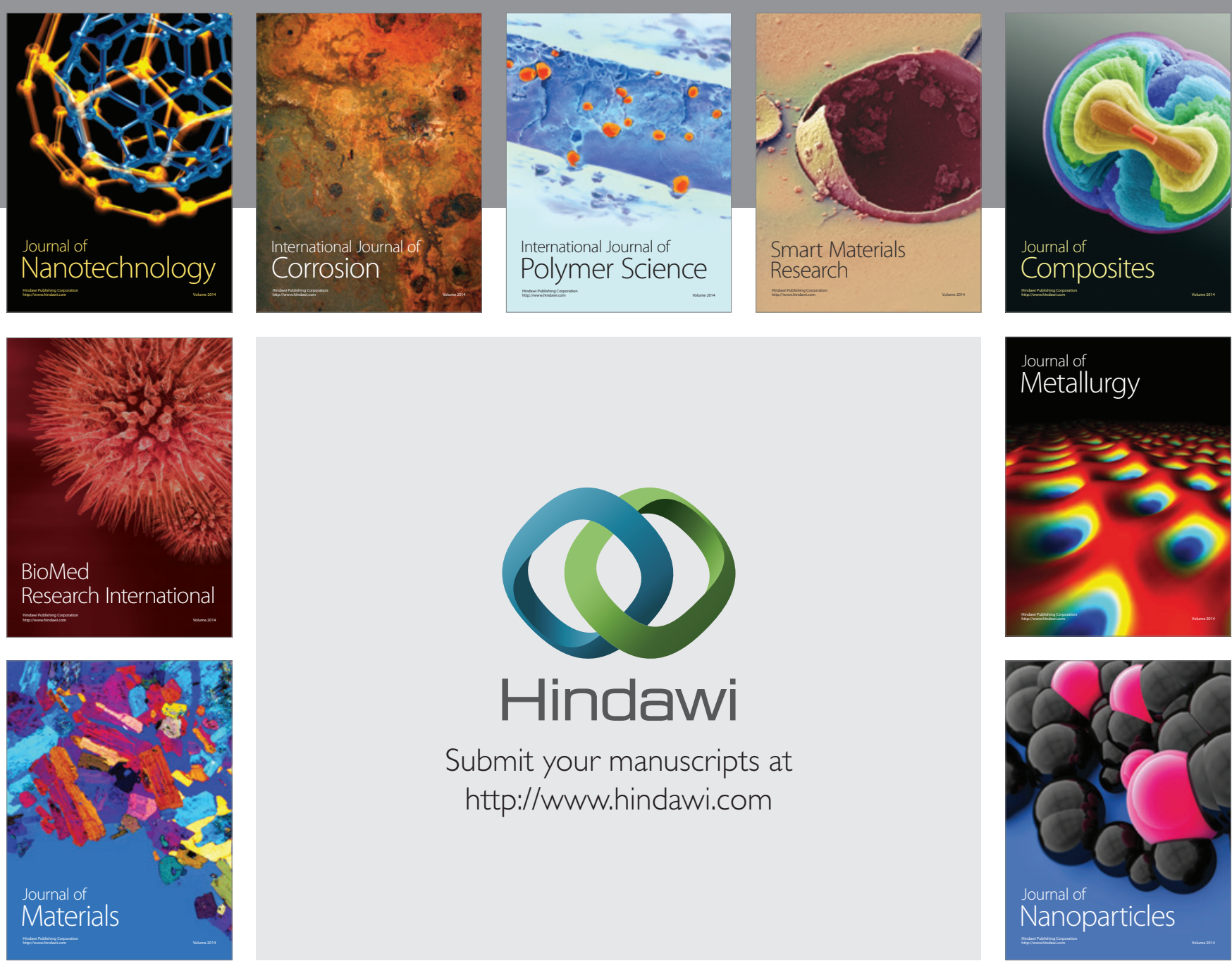

\section{Hindawi}

Submit your manuscripts at

http://www.hindawi.com

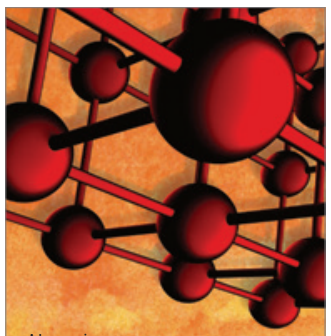

Materials Science and Engineering
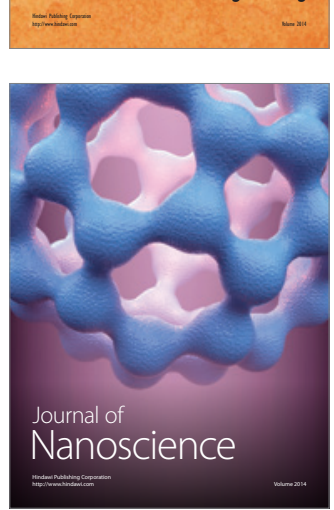
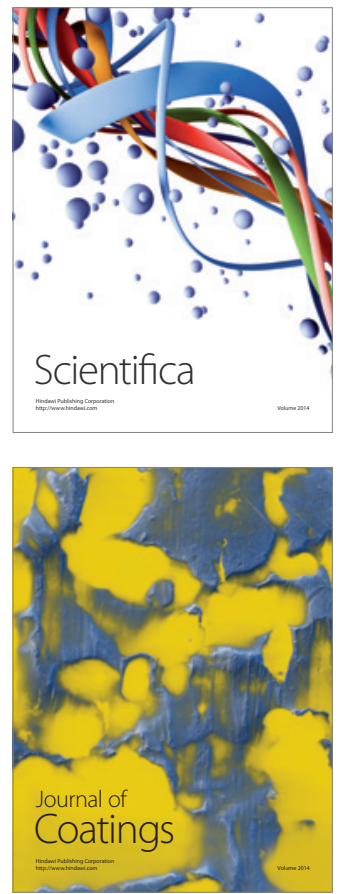
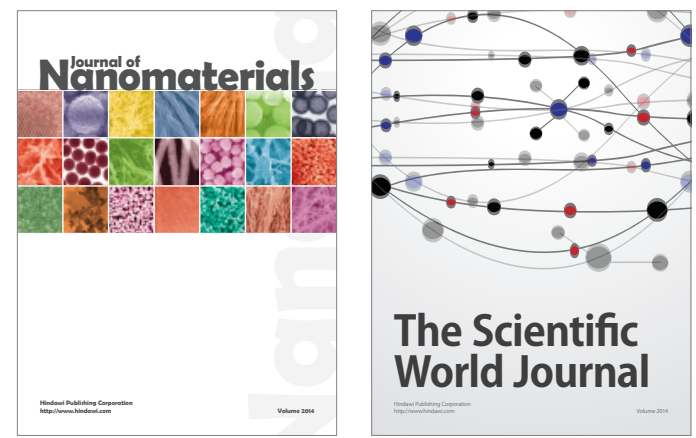

The Scientific World Journal
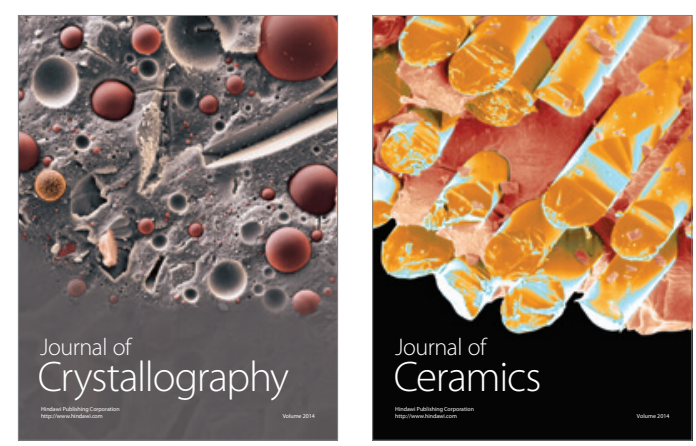
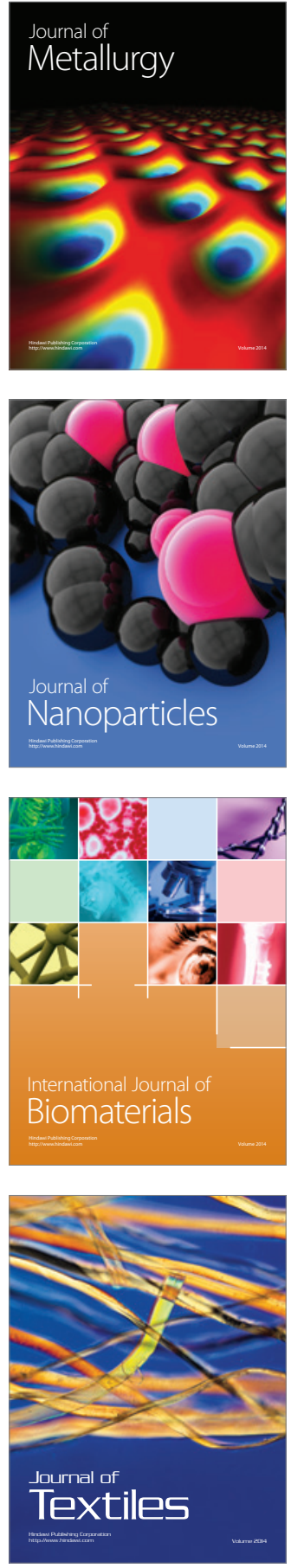